\title{
How Women Leaders Can Bounce Back from Covid-19
}

\author{
Elizabeth Bagnall (Beaufort Group Consulting) \\ Dr. Susan Laverick (House of Beaufort)
}

KEYWORDS: Entrepreneurship, Women.

While both men and women may be struggling to balance work and family commitments during the unique challenges posed by the Covid-19 environment, the bulk of childcare and eldercare has tended to fall on women. Our EIX article, shared here, suggests approaches that might help women to move forward in the next few months, especially by creating personal boundaries that will offer vital flexibility in these uncertain times.

Women: Regain Your Professional Footing (https://familybusiness.org/content/women-regain-yourprofessional-footing) 